\title{
Manajemen Risiko Divisi Sistem Informasi Perguruan Tinggi dengan Framework COBIT 5
}

\author{
http://dx.doi.org/10.28932/jutisi.v7i1.3434 \\ Riwayat Artikel \\ Received: 22 Februari 2021 | Final Revision: 4 Maret 2021 | Accepted: 12 Maret 2021
}

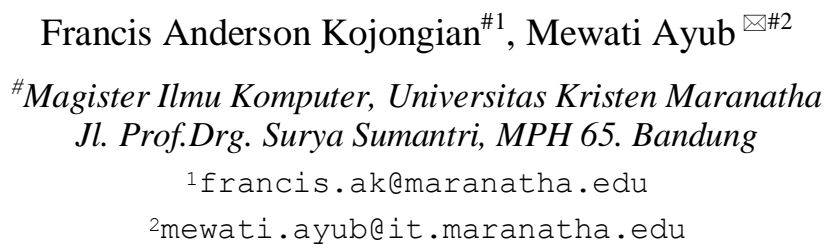

Abstract - In order to achieve the company goals, in Higher Education, Information system becomes the main tool and Information Technology infrastructure become the backbone in running the company business model, along with the increasing of portfolio application, number of Information Technology services and the amount of human resources. Division of Information Technology in Higher Education requires an international standard instrument to measure several domains, both Manage and Operation domains, holistically. By implementing frameworks such as COBIT 5 or COBIT 5 for IT RISK, ISO 31000: 2018, the company is able to measure planning effectiveness, strategic policies implementation, IT service management measured by Service Level Agreement, monitoring and evaluation. In this research, there are 7 domains implemented as follows: EDM01-Ensure Governance Framework Setting and Maintenance, EDM03- Ensure Risk Optimization, AP002- Manage Strategy, APO09- Manage Service Agreements, AP012-Manage Risk, BAI01-Manage Programmes and Projects, BAI05- Manage Organizational Change Enablement.

Keywords - COBIT 5; IT Governance; Risk Management; ISO 31000:2018.

\section{Pendahuluan}

Sebuah perguruan tinggi swasta yang berada di Kota Bandung, Jawa Barat, Indonesia dalam perjalanannya selama 55 tahun terus mengalami perkembangan dan hingga saat ini universitas ini memiliki 9 Fakultas dengan 28 Program Studi (Jenjang Studi Diploma, Sarjana, Profesi, dan Magister).

Dalam menjalankan bisnis model sebagai perguruan tinggi, penggunaan teknologi informasi menjadi standar pengelolaan bisnis perguruan tinggi. Seiring dengan perkembangan proses bisnis, sistem informasi mengalami pertumbuhan ditandai dengan bertambahnya jumlah sistem informasi dalam application portfolio, dan bertambahnya jumlah Service Level Agreement tahun 2014 [1].
Meningkatnya jumlah sistem informasi dalam rangka mencapai tujuan organisasi dan merupakan kebutuhan yang tidak terhindarkan. Selain faktor ketersediaan sumber daya, faktor lain adalah bagaimana perguruan tinggi dapat beradaptasi dengan kebutuhan pasar dan kebutuhan regulator pendidikan tinggi. Saat ini perguruan tinggi berpikir keras dan mencari strategi yang efektif dan tepat, dalam rangka mengembangkan IT Enterprise Architecture yang selaras dengan kebutuhan enterprise. Selain dengan mengelola sistem informasi secara mandiri, menambah sumberdaya eksternal merupakan pilihan yang tidak terhindarkan.

Berdasarkan latar belakang tersebut, maka disusunlah rumusan masalah yang sedang dihadapi Divisi Pengelolaan Sistem Informasi Perguruan Tinggi XYZ, sebagai berikut:

1. Perguruan tinggi harus lebih memperhatikan aplikasi strategis yang dikembangkan oleh pihak ketiga yang banyak menggunakan data-data primer atau sekunder untuk kebutuhan Development atau Testing.

2. Cara menyusun mekanisme Assesment Model Audit untuk pengelolaan proyek, pengelolaan risiko, yang sesuai dengan framework yang akan dipilih yang berfokus pada beberapa domain spesifik.

Melihat pada masalah-masalah tersebut maka dilakukan penelitian tentang Manajemen Risiko Divisi Sistem Informasi Perguruan Tinggi Dengan Framework COBIT 5

Tujuan penelitian, merupakan harapan kepada Divisi Pengelolaan Sistem Informasi Perguruan Tinggi, yaitu:

1. Memiliki nilai capability dan index maturity untuk sistem informasi dalam application portfolio yang dikelola dan memiliki ukuran yang jelas apa yang harus dipertahankan atau dikembangkan dengan segala potensi dan nilai risiko yang terukur.

2. Memiliki rekomendasi kebijakan strategis untuk pengelolaan sistem informasi. Application portfolio yang dikembangkan secara internal atau yang melibatkan pihak eksternal (vendor) dalam kontrak pengerjaannya, tata 
kelola organisasi menyediakan policy terkait dengan pemanfaatan asset TI data primer atau sekunder yang secara jelas memiliki proteksi melalui kebijakan pemanfaatan data untuk kebutuhan development and testing.

Ruang lingkup penelitian pada Divisi Pengelolaan Sistem Informasi Perguruan Tinggi XYZ periode tahun 2018-2020 [2] yang merupakan unit kerja yang bertanggung jawab dalam menjalankan operasional TI

Lingkup dari penelitian yang berdasarkan perspektif yang memisahkan antara governance and manage adalah mengukur dan memetakan rencana strategis dan tujuan strategis yang sejalan dengan eksekusi dalam management. Terdapat 2 (dua) perspektif yaitu perspektif enterprise governance/tata kelola enterprise (pengelolaan strategi atau kebijakan) dan perspektif manage yang berfokus pada tujuan dan target strategis. Kedua perspektif tersebut bersinergi dalam memenuhi enterprise goals dan tujuan tata kelola TI. Dalam penelitian ini, kedua perspektif tersebut digunakan untuk identifikasi potensi ancaman dan rekomendasi analisis risiko yang akan menggunakan framework COBIT 5 dengan fokus pada domain EDM03-Memastikan Pengoptimalan Risiko dan domain APO12-Mengelola Risiko dan beberapa sub domain pendukung seperti: EDM01-Ensure Governance Framework Setting and Maintenance, EDM03-Ensure Risk Optimation, AP002- Manage Strategy, APO09-Manage Service Agreements, AP012-Manage Risk, BAI01-Manage Programmes and Projects, BAI05- Manage Organisational Change Eneblement.

\section{Model Kebutuhan Dan Analisis}

\section{A. Metode Penelitian}

Metode yang dilakukan untuk penelitian ini adalah persiapan sumber data dengan cara melakukan wawancara dengan stakeholder, studi literatur, identifikasi dan pemetaan strategis, mapping IT related goals dan proses dalam COBIT 5 , identifikasi masalah dan penentuan domain area analis, desain kuesioner, penentuan responden, menyebarkan kuesioner, mengolah kuesioner dan analisis data untuk pengukuran tingkat kapabilitas dan tingkat kematangan proses, pembuatan rekomendasi, dan tahapan akhir adalah kesimpulan dan saran. Metode yang dilakukan seperti terlihat pada Gambar 1.

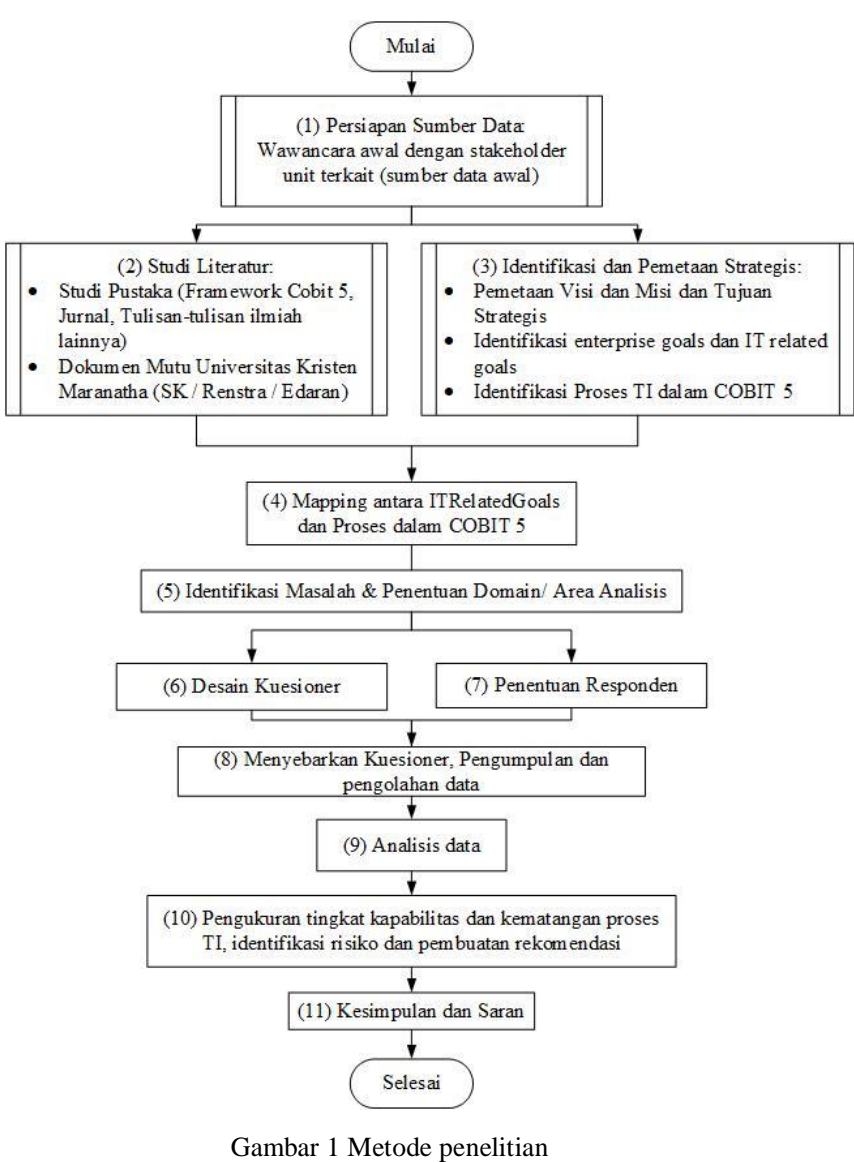

Data yang digunakan dalam penelitian ini terdiri atas 2 (dua) sumber data utama yaitu data hasil survey yang disebarkan pada stakeholders dan data hasil wawancara dengan pimpinan dan staf Divisi Pengelolaan Sistem Informasi Perguruan Tinggi yang dilengkapi dengan analisis dokumen mutu dan bukti-bukti workproduct.

\section{B. Manajemen Risiko [3]}

Secara terminologi Risiko (risk) adalah ketidakpastian yang berdampak pada sasaran. Dampak merupakan penyimpangan (deviasi) dari sasaran yang diharapkan, sasaran dapat mempunyai berbagai macam bentuk dan kategori, dan dapat diterapkan pada berbagai organisasi. Kecepatan risiko menunjukkan seberapa cepat waktu yang diperlukan dari saat risiko terindentifikasi hingga berubah menjadi peristiwa risiko. Persistensi risiko menunjukkan adanya paparan risiko yang bertahan lama.

Manajemen risiko dalam pengertian yang lebih sederhana yaitu:

1. Penentuan sasaran (objective),

2. Melihat atau memperkirakan peristiwa apa saja yang dapat mengganggu pencapaian sasaran (risk identification and risk analysis),

3. Memperkirakan peristiwa mana saja yang paling gawat (risk evaluation), 
4. Melakukan tindakan untuk mengatasi kemungkinan dan dampak terjadinya peristiwa-peristiwa yang gawat (risk treatment),

5. Memeriksa apakah tindakan perlakuan risiko yang dilakukan berhasil (monitoring and review), dan

6. Memeriksa terjadi perubahan lingkungan atau organisasi yang mempengaruhi perlakuan risiko (monitoring and review).

\section{Hipotesis}

Berdasarkan rumusan masalah, landasan teori, tinjauan pustaka dan analisis awal maka didapatkan hipotesis penelitian sebagai berikut:

1. $\mathrm{H}_{1}$, Diduga Divisi Pengelolaan Sistem Informasi Perguruan Tinggi XYZ, dalam mengelola proyek sistem informasi aplikasi strategis atau aplikasi utama yang melibatkan pihak ketiga, yang melibatkan atau menggunakan asset TI primer atau sekunder dalam domain pengoptimalisasian risiko, mengelola risiko, mengelola proyek TI berada pada lack of evidence and lack of control atau pada skala kapabilitas level Performed.

2. $\mathrm{H}_{2}$, Diduga Divisi Pengelolaan Sistem Informasi Perguruan Tinggi XYZ, untuk domain ensure governance dan manage service berada pada level Established.

\section{Tata Kelola TI}

Tata Kelola TI merupakan suatu bentuk komitmen, kesadaran dan proses pengendalian manajemen organisasi terhadap sumber daya TI, mulai dari sumber daya komputer (software, brainware, database dan sebagainya) hingga ke Teknologi Informasi dan Jaringan LAN/Internet. Terdapat banyak pengertian dan pendapat mengenai Tata Kelola (Governance) TI [4].

Menurut COBIT 5 yang menjadi standar umum Tata Kelola TI dari lembaga ISACA, Tata Kelola TI didefinisikan sebagai "structure of relationships and processes to direct and control the enterprise in order to achieve the entreprise's goals by value while balancing risk versus return over IT and its processes". Sedangkan Oltsik (2003) mendefinisikan IT Governance sebagai kumpulan kebijakan, proses/aktivitas dan prosedur untuk mendukung pengoperasian TI agar hasilnya sejalan dengan strategi bisnis (strategi organisasi).

Dari kumpulan definisi mengenai Tata Kelola TI tersebut, maka dapat disimpulkan bahwa tujuan dibangunnya Tata kelola TI pada dasarnya untuk menyelaraskan sumberdaya TI dengan tujuan dan strategi organisasi serta dapat berfungsi sebagai enabler [4]. Untuk mewujudkan IT Governance dalam suatu organisasi, maka suatu organisasi harus membangun struktur yang dinamakan dengan IT Governance Framework, dengan pola sebagai berikut:

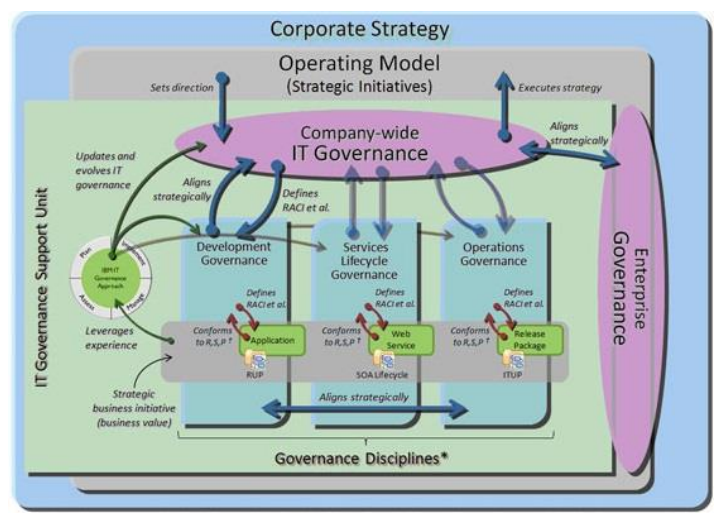

Gambar 2 Tata Kelola TI [4]

\section{E. Framework COBIT 5}

COBIT 5 adalah edisi terbaru dari Framework COBIT ISACA yang menyediakan penjabaran bisnis secara end-toend dari Tata Kelola TI perusahaan untuk menggambarkan peran utama dari informasi dan teknologi dalam menciptakan nilai perusahaan.

COBIT 5 adalah sebuah versi pembaharuan yang menyatukan cara berpikir yang mutakhir di dalam teknikteknik dan Tata Kelola TI perusahaan. Menyediakan prinsipprinsip, praktik-praktik, alat-alat analisis yang telah diterima secara umum untuk meningkatkan kepercayaan dan nilai sistem-sistem informasi. Pemisahan governance dan management dalam COBIT 5 dapat dilihat pada Gambar 3.

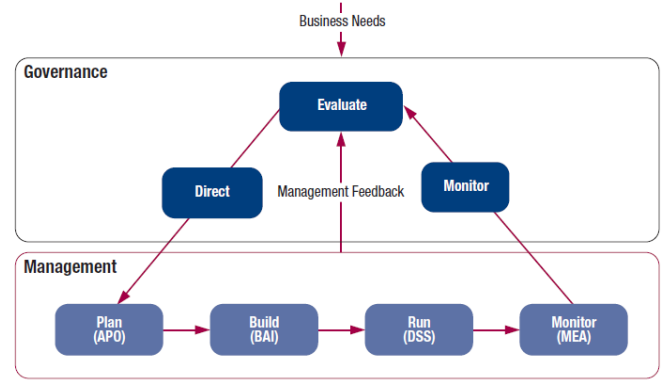

Gambar 3 Pemisahan Governance and management

\section{F. Prinsip-prinsip dalam COBIT 5}

Terdapat 5 (lima) prinsip dalam COBIT 5 [5] dalam tata kelola dan manajemen TI, yaitu:

1. Pemenuhan kebutuhan stakeholder (meeting stakeholder needs).

2. Melindungi titik-titik penting perusahaan (covering the enterprise end-to-end).

3. Penggunaan sebuah framework terintegrasi (applying a single integrated framework).

4. Memungkinkan pendekatan secara holistik (enabling a holistic approach.)

5. Memisahkan tatakelola dengan manajemen (separating governace from management)

Gambar 4 merupakan diagram 5 prinsip COBIT 5. 


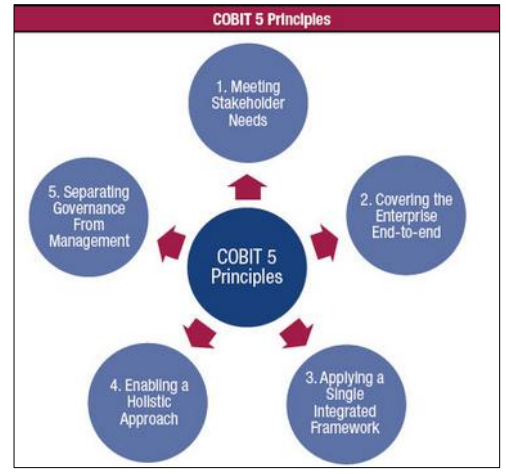

Gambar 4 Prinsip-prinsip dalam COBIT

\section{G. Capability Model dan Rating Atribute}

Berbeda dengan cobit versi sebelumnya. Pada COBIT versi 4.1 yang menggunakan maturity model untuk pengukuran tingkat kematangan suatu proses. COBIT 5 memperkenalkan proses tingkat kematangan yang baru menggunakan capability model. Semua proses pada masingmasing domain tersebut memiliki capability model yang sudah didefinisikan dan sesuai dengan skala pengukuran mulai dari mulai dari Level 0 - Incomplete Process sampai dengan Level 5 Optimizing Process. Proses ini sudah merupakan best practices dari proses yang matang dengan level, atribut proses dan skala atribut seperti pada Gambar 5.

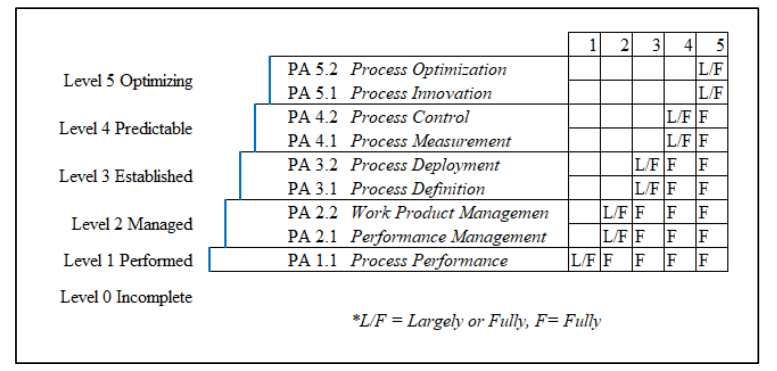

Gambar 5 Level kapabilitas Process Assessment Model

Skala yang digunakan untuk menilai atribute PA 1.1 sampai dengan PA 5.2 pada Gambar 5, dengan rating scale [6] yaitu:

- $\mathrm{N}$ adalah not achieved (0 s.d. 15\%). Terdapat sedikit atau tidak sama sekali bukti implementasi.

- $\mathrm{P}$ adalah partial achieved (15\% s.d. 50\%). Terdapat beberapa bukti.

- L adalah largely achieved (50\% s.d. 85\%). Terdapat beberapa bukti sistematik dan pencapaian signifikan. Terdapat kelemahan pada atribut yang dinilai.

- F adalah fully achieved (85\% s.d. 100\%). Terdapat bukti lengkap dengan pendekatan sistematik, pencapaian penuh tidak terdapat kelemahan pada atribut yang dinilai.

\section{H. Metode Analisis Data}

Metode yang digunakan untuk analisis data menggunakan Process Assessment Model COBIT 5 [6]. Data yang sudah diperoleh dari sampel dapat digeneralisasikan pada populasi, data yang dikumpulkan diolah dan dikelompokan pada beberapa tahapan sebagai berikut:

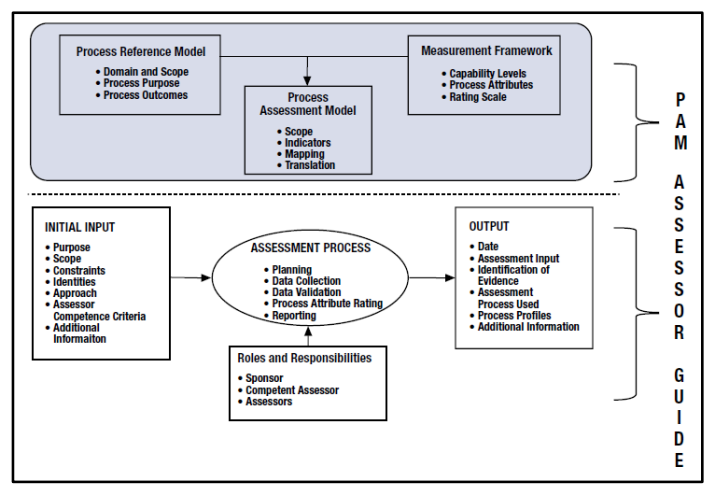

Gambar 6 Process Assessment Model - Sumber: This figure is reproduced from ISO/IEC 15504-2, with the permission of ISO/IEC at www.iso.org. Copyright remains with ISO/IEC

\section{HASIL PENELITIAN}

\section{A. Persiapan Data}

Sesuai dengan lingkup penelitian yang dilakukan, objek penelitian saat ini pada unit kerja yang menangani bidang pengembangan perangkat lunak, pada tahap ini yang dilakuan adalah pemetaan enterprise goal dan IT related goals yang sesuai dengan pemetaan visi dan misi atau tujuan strategis perusahaan [7].

Berdasarkan matriks tujuan strategis perusahaan yang sudah ditetapkan, Enterprise Goals dipetakan, dimana $\mathrm{P}=$ Primer, dan $\mathrm{S}=$ Sekunder, dan masing-masing enterprise goal diberikan nilai sesuai dengan poin referensi pada tujuan strategis 1.1 s.d. 5.6. Hasil pemetaan dapat dilihat pada TABEL I.

TABEL I

PEMETAAN ENTERPRISE GOAL DENGAN TUJUAN STRATEGIS

\begin{tabular}{|c|c|c|c|}
\hline $\begin{array}{c}\text { BSC } \\
\text { Dimension }\end{array}$ & \multirow{2}{*}{\multicolumn{2}{|c|}{$\begin{array}{l}\text { Enterprise Goal } \\
\begin{array}{l}\text { Stakeholder value of } \\
\text { business investments }\end{array}\end{array}$}} & \multirow{2}{*}{$\begin{array}{l}\begin{array}{l}\text { Benefit } \\
\text { Realisation }\end{array} \\
\text { P (TS 5.2, } \\
5.3,5.4,5.6) \\
\end{array}$} \\
\hline \multirow{4}{*}{ Financial } & & & \\
\hline & 2 & $\begin{array}{l}\text { Portfolio of competitive } \\
\text { products and services }\end{array}$ & $\mathrm{P}(\mathrm{TS} 5.5)$ \\
\hline & 3 & $\begin{array}{l}\text { Managed business risk } \\
\text { (safeguarding of assets) }\end{array}$ & $\mathrm{S}$ \\
\hline & 4 & $\begin{array}{l}\text { Compliance with external } \\
\text { laws and regulations }\end{array}$ & $\mathrm{S}$ \\
\hline \multirow{4}{*}{ Customer } & 5 & Financial transparency & $\mathrm{S}$ \\
\hline & 6 & $\begin{array}{l}\text { Customer-oriented service } \\
\text { culture }\end{array}$ & $\begin{array}{l}\mathrm{P}(\mathrm{TS} 4.1, \\
4.3)\end{array}$ \\
\hline & 7 & $\begin{array}{l}\text { Business service } \\
\text { continuity and availibility }\end{array}$ & $\begin{array}{l}\mathrm{P}(\mathrm{TS} 4.1 \\
4.3)\end{array}$ \\
\hline & 8 & $\begin{array}{l}\text { Agile responses to a } \\
\text { changing business } \\
\text { environment }\end{array}$ & \\
\hline Internal & 9 & $\begin{array}{l}\text { Information-based } \\
\text { strategic decision making }\end{array}$ & $\begin{array}{l}\text { P (TS: } 1.4 \\
1.5)\end{array}$ \\
\hline
\end{tabular}




\begin{tabular}{|c|c|c|c|}
\hline \multirow[t]{7}{*}{$\begin{array}{c}\text { BSC } \\
\text { Dimension }\end{array}$} & \multicolumn{2}{|r|}{ Enterprise Goal } & \multirow{2}{*}{$\begin{array}{l}\begin{array}{l}\text { Benefit } \\
\text { Realisation }\end{array} \\
\mathrm{S}\end{array}$} \\
\hline & 10 & $\begin{array}{l}\text { Optimisation of service } \\
\text { delivery costs }\end{array}$ & \\
\hline & 11 & $\begin{array}{l}\text { Optimisation of business } \\
\text { process functionality }\end{array}$ & P (TS: 1.5) \\
\hline & 12 & $\begin{array}{l}\text { Optimisation of business } \\
\text { process cost }\end{array}$ & P (TS: 3.3) \\
\hline & 13 & $\begin{array}{l}\text { Manage business change } \\
\text { programmes }\end{array}$ & $\mathrm{S}$ \\
\hline & 14 & $\begin{array}{l}\begin{array}{l}\text { Operational and staff } \\
\text { productivity }\end{array} \\
\end{array}$ & P (TS: 3.3) \\
\hline & 15 & $\begin{array}{l}\text { Compliance with internal } \\
\text { policies }\end{array}$ & $\begin{array}{l}\text { P (TS: 3.1, } \\
3.3)\end{array}$ \\
\hline \multirow{2}{*}{$\begin{array}{l}\text { Learning } \\
\text { and } \\
\text { Growth }\end{array}$} & 16 & $\begin{array}{l}\text { Skilled and motivated } \\
\text { people }\end{array}$ & P (TS: 2.1) \\
\hline & 17 & $\begin{array}{l}\text { Product and business } \\
\text { innovation culture }\end{array}$ & $\begin{array}{l}\text { P (TS: } 2.2, \\
2.3,2.4)\end{array}$ \\
\hline \multicolumn{3}{|c|}{ Jumlah P } & $11(68.75 \%)$ \\
\hline \multicolumn{3}{|c|}{ Jumlah S } & $6(31.25 \%)$ \\
\hline \multicolumn{3}{|r|}{ Total } & $100 \%$ \\
\hline
\end{tabular}

Berdasarkan Tabel I jumlah P (primer) $=68.75 \%$ dan $\mathrm{S}$ (sekunder) $=31.25 \%$ selanjutnya untuk pemetaan IT Related Goals hanya akan diambil enterprise goal yang bernilai $\mathrm{P}$ atau total sebanyak 11 enterprise goals.

TABEL II

PEMETAAN IT RELATED GOALAND ENTERPRISE GOAL

\begin{tabular}{|c|c|c|c|c|c|c|c|c|c|c|c|c|}
\hline \multirow{2}{*}{\multicolumn{2}{|c|}{$\begin{array}{l}\text { Enterpr } \\
\text { ise Goal } \\
\text { IT } \\
\text { Related } \\
\text { Goal }\end{array}$}} & \multicolumn{3}{|c|}{$\begin{array}{c}\text { Financia } \\
l\end{array}$} & \multicolumn{6}{|c|}{ Internal } & \multicolumn{2}{|c|}{$\begin{array}{c}\text { Learnin } \\
\text { g\& } \\
\text { Growth }\end{array}$} \\
\hline & & 1 & 2 & 3 & 7 & 8 & 9 & 10 & 11 & 15 & 16 & 17 \\
\hline \multirow{3}{*}{ 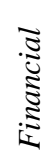 } & 1 & $P$ & $P$ & & & & $P$ & $P$ & & & & \\
\hline & 4 & & & $\mathrm{P}$ & & & & & & & & \\
\hline & 7 & & & & $P$ & & & & $\mathrm{P}$ & & & \\
\hline \multirow{4}{*}{ 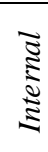 } & 9 & & & & $\mathrm{P}$ & $\mathrm{P}$ & & & & & & \\
\hline & 11 & & & $P$ & & & & & & & & \\
\hline & 13 & & & & & & & & $P$ & $\mathrm{P}$ & & \\
\hline & 15 & & $\mathrm{P}$ & & $P$ & & & & & & & \\
\hline $\begin{array}{l}L \\
\& \\
G\end{array}$ & 17 & & & & & & & & & & & $\mathrm{P}$ \\
\hline
\end{tabular}

Berdasarkan Tabel II, ditentukan pemetaan untuk 11 enterprise goals utama dan 8 IT related goals, yang kemudian akan dipetakan kedalam 7 domain proses dalam COBIT 5. Terkait dengan pemetaan IT related goal dan enterprise goal setelah memiliki data mapping IT related goals dan enterprise goal akan dipetakan kedalam process reference model.
TABEL III

PEMETAAN PROCESS REFERENCE MODEL DAN IT RELATED GOAL

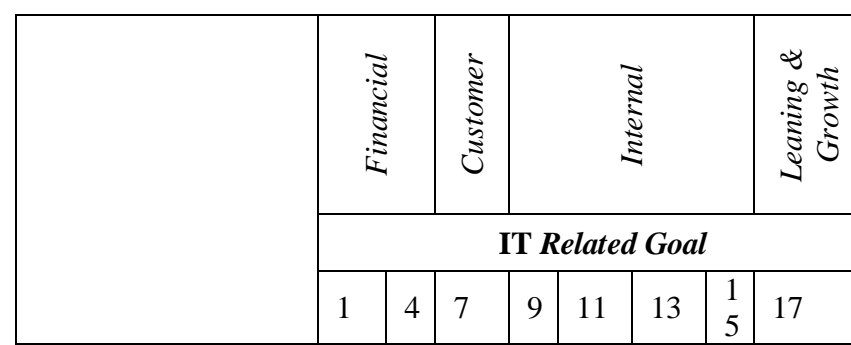

Process Reference Model

Governance: Evaluate, Direct and Monitor

\begin{tabular}{l|l|l|l|l|l|l|l|l}
$\begin{array}{l}\text { EDM01- Ensure } \\
\text { Governance } \\
\begin{array}{l}\text { Framework Setting } \\
\text { and Maintenance }\end{array}\end{array}$ & P & $\mathbf{P}$ & & & & & & \\
\hline $\begin{array}{l}\text { EDM03 - Ensure } \\
\text { Risk Optimisation }\end{array}$ & & $\mathbf{P}$ & & & $\mathbf{P}$ & $\mathbf{P}$ & & \\
\hline
\end{tabular}

Risk Optimisation

\begin{tabular}{|c|c|c|c|c|c|c|c|}
\hline $\begin{array}{l}\text { APO02- Manage } \\
\text { Strategy }\end{array}$ & $\mathbf{P}$ & $\mathbf{P}$ & $\mathbf{P}$ & & & & \\
\hline $\begin{array}{l}\text { APO09- Manage } \\
\text { Service Agreements }\end{array}$ & & & & $\mathbf{P}$ & $\mathbf{P}$ & & \\
\hline $\begin{array}{l}\text { APO12- Manage } \\
\text { Risk }\end{array}$ & & $\mathbf{P}$ & & & & $\mathbf{P}$ & \\
\hline \multicolumn{8}{|c|}{ Management: Build, Acquire and Operate } \\
\hline $\begin{array}{l}\text { BAI01- Manage } \\
\text { Programmes and } \\
\text { Projects }\end{array}$ & $\mathbf{P}$ & & $\mathbf{P}$ & $\mathbf{P}$ & & $\mathbf{P}$ & $\mathbf{P}$ \\
\hline $\begin{array}{l}\text { BAI05- Manage } \\
\text { Organisational } \\
\text { Change Enablement }\end{array}$ & & & $\mathbf{P}$ & $\mathbf{P}$ & $\mathbf{P}$ & & \\
\hline
\end{tabular}

Berdasarkan Tabel III angka pada kolom IT related goal kolom 1 adalah Alignment of IT and Bussines Strategy, 2 adalah Managed IT-related business risk, 7 adalah Delivery of IT services in line with business requirements, 9 adalah IT Agility, 11 adalah Optimisation of IT assets, resources and capabilities, 13 adalah Delivery of programmes delivering benefits, on time, on budget, and meeting requirements and quality standards, 15 adalah IT compliance with internal policies dan 17 adalah Knowlede, expertise and initiatives for business innovation.

Sesuai dengan Tabel III di atas total terdapat 7 (tujuh) domain analisis Process Reference Model (PRM) akan berfokus pada domain governance, area Evaluate, Direct and Monitor yang memiliki 2 (dua) sub domain yaitu: EDM01Ensure Governance Framework Setting and Maintenance dan EDM03-Ensure Risk Optimation. Kemudian untuk domain Management area Align, Plan and Organize memiliki 3 (tiga) sub domain, yaitu: APO02-Manage Strategy, APO09-Manage Service Agreements dan APO12Manage Risk. Area Build, Acquire and Implement memiliki 2 (dua) sub domain, yaitu: BAI01-Manage Programmes and Projects dan BAI05-Manage Organisational Change Eneblemen 


\section{B. Pemetaan Menggunakan RACI Chart}

Pemetaan RACI Chart dilakukan untuk pemetaan keterlibatan masing-masing stakeholders yang sesuai dengan proses primer dalam enterprise goal dan IT related goal. Pada tahap ini keterlibatan pihak secara spesifik dipetakan ke dalam domain area control dalam COBIT 5, yang responsible, accountable, consulted dan informed.

TABEL IV

PEMETAAN RESPONSIBILITIES IN IT GOALS

\begin{tabular}{|c|c|c|c|c|c|c|c|c|}
\hline Stakeholders & $\sum_{\substack{ \pm 2}}$ & 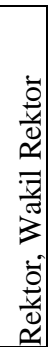 & 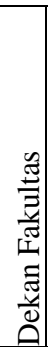 & 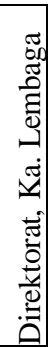 & 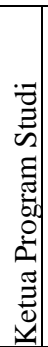 & 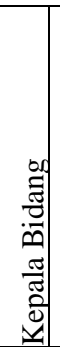 & 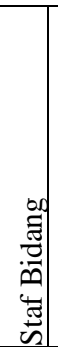 & 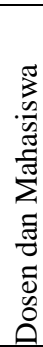 \\
\hline $\begin{array}{l}\text { EDM01- Ensure } \\
\text { Governance Framework } \\
\text { Setting and Maintenance } \\
\text { (Visi, Misi, Tujuan Sasaran } \\
\text { dan Nilai) }\end{array}$ & A & $\mathrm{R}$ & I & I & I & I & I & I \\
\hline $\begin{array}{l}\text { EDM01- Ensure } \\
\text { Governance Framework } \\
\text { Setting and Maintenance } \\
\text { (Renstra Universitas) }\end{array}$ & A & $\mathrm{R}$ & I & I & I & I & I & I \\
\hline \multirow{2}{*}{$\begin{array}{l}\text { APO02-Manage Strategy } \\
\text { (Tujuan Strategi Universitas) } \\
\text { EDM03-Ensure Risk } \\
\text { Optimisation }\end{array}$} & $\mathrm{C}$ & A & $\mathrm{R}$ & $\mathrm{R}$ & I & I & I & I \\
\hline & C & $\mathrm{A}$ & $\mathrm{R}$ & $\mathrm{R}$ & I & I & I & I \\
\hline Program Kerja Fakultas & & $\mathrm{C}$ & $\mathrm{R}$ & & I & I & I & I \\
\hline $\begin{array}{l}\text { Program Kerja Unit } \\
\text { Berdasarkan TS Universitas }\end{array}$ & & $\mathrm{C}$ & & A & $\mathrm{R}$ & $\mathrm{R}$ & $\mathrm{R}$ & I \\
\hline $\begin{array}{l}\text { APO09-Manage Service } \\
\text { Agreements }\end{array}$ & & & & $\mathrm{C}$ & I & $\mathrm{R}$ & I & I \\
\hline APO12-Manage Risk & & A & & $\mathrm{C}$ & & $\mathrm{R}$ & I & I \\
\hline $\begin{array}{l}\text { BAI01-Manage } \\
\text { Programmes and Projects }\end{array}$ & & $\mathrm{A}$ & & $\mathrm{C}$ & & $\mathrm{R}$ & I & I \\
\hline $\begin{array}{l}\text { BAI05-Manage } \\
\text { Organisational Change } \\
\text { Enablement }\end{array}$ & A & $\mathrm{C}$ & $\mathrm{R}$ & $\mathrm{R}$ & I & I & I & I \\
\hline
\end{tabular}

Tabel IV merupakan informasi pemetaan yang menggunakan model pemetaan RACI Chart. (R) yang bertanggung jawab mengerjakan EDM01-Ensure Governance Framework Setting and Maintenance bagian Visi, Misi, Tujuan Sasaran dan Nilai dan bagian Renstra Universitas adalah Pimpinan Universitas (Rektor, Wakil Rektor).

Sedangkan untuk domain EDM01 yang berhak membuat keputusan akhir (A) adalah YPTKM. APO02-Manage Strategy (Tujuan Strategi Universitas) yang bertanggung jawab untuk mengerjakan (R) adalah Dekan Fakultas, Direktur, Ketua Lembaga, Kepala Badan. EDM03-Ensure
Risk Optimisation orang yang bertanggung jawab mengerjakan (R) adalah Dekan Fakultas, Direktur, Ketua Lembaga. Untuk menjalankan program kerja berdasarkan tujuan strategis level fakultas adalah Dekan Fakultas dan pimpinan level unit kerja (Direktur, Ketua Lembaga).

Untuk APO09-Manage Service Agreements, APO12Manage Risk dan BAI01-Manage Programmes and Projects orang yang bertanggung jawab adalah Kepala Bidang. Cara untuk membaca pemetaan berdasarkan pola pada Tabel 7 di atas adalah mulai melihat dari (R) kemudian level di bawah mendapatkan (I) atau informed dan (A) untuk siapa yang membuat keputusan akhir, dan naik banding 1(satu) level untuk $(\mathrm{C})$ orang yang menerima konsultasi sebelum proses dilanjutkan.

\section{Perhitungan Kapabilitas Saat Ini}

Pada Tabel V berikut akan menampilkan hasil analisis untuk semua domain yang area kontrol. Dengan ditemukan nilai kapabilitas saat ini [8], dikurangi dengan nilai yang diharapkan, sehingga data Gap bisa terlihat. Secara keseluruhan dapat dilihat pada Tabel V.

TABEL V

Hasil PENGUKuRAn TingKat KaPABILITAS UntUK 7 DOMAIN

\begin{tabular}{|c|c|c|c|c|c|c|}
\hline $\begin{array}{l}\text { Area } \\
\text { Kontrol }\end{array}$ & 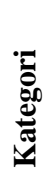 & & 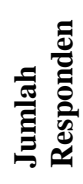 & 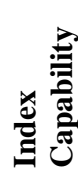 & 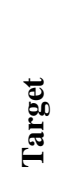 & बैं \\
\hline EDM01 & 1 & 20 & 7 & 3.59 & 5.0 & 1.41 \\
\hline APO02 & \multirow{3}{*}{2} & \multirow{3}{*}{13} & \multirow{3}{*}{23} & \multirow{3}{*}{3.82} & \multirow{3}{*}{5.0} & \multirow{3}{*}{1.18} \\
\hline EDM03 & & & & & & \\
\hline BAI05 & & & & & & \\
\hline APO09 & \multirow{3}{*}{3} & \multirow{3}{*}{35} & \multirow{3}{*}{22} & \multirow{3}{*}{3.25} & \multirow{3}{*}{5.0} & \multirow{3}{*}{1.75} \\
\hline APO12 & & & & & & \\
\hline BAI01 & & & & & & \\
\hline \multirow{2}{*}{ Pengguna } & 4 & 6 & 24 & 4.32 & 5.0 & 0.68 \\
\hline & 5 & 2 & 34 & 4.01 & 5.0 & 0.99 \\
\hline Total & & 76 & 110 & 3.80 & 5.0 & 1.20 \\
\hline
\end{tabular}

Tabel V memperlihatkan kondisi aktual saat ini current level berada pada level kapabilitas dengan score 3.80, dengan target yang diharapkan adalah kapabilitas level dengan score 5 maka masih terdapat kesenjangan antara kondisi terkini dan kondisi yang diharapkan dengan nilai sebesar 1.2 dengan visualisasi data pada Gambar 7. 


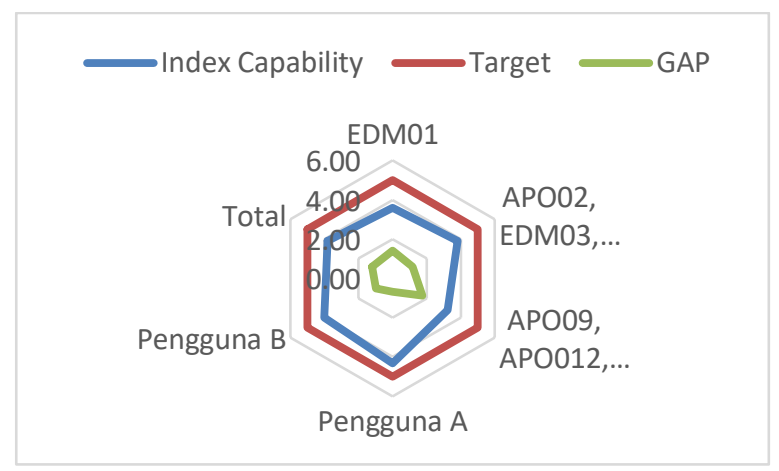

Gambar 7 Grafik Analisis Tingkat Kapabilitas 7 Domain

Berdasarkan Gambar 7 kondisi kesenjangan yang terlihat dijadikan sebagai nilai acuan awal, untuk melanjutkan analisis apakah terdapat kesesuaian dengan hipotesis yang sudah dibuat sebelumnya. Sesuai metode analisis data Gambar 7, dilanjutkan dengan proses assesment untuk mengukur atribut masing-masing proses dengan tabel pengujian yang sudah disiapkan atau sesuai dengan tujuan area domain kontrol yang sudah ditentukan.

Selanjutnya adalah Process Assesment Model (PAM) [6]. Tahap ini merupakan tahapan pengukuran tingkat kematangan masing-masing level untuk mengukur performansi berdasarkan Process Reference Model [9] yang disediakan COBIT 5 rating scale domain analisis dan untuk masing-masing proses mulai dari PA 1.1 s.d. PA 5.1 yang sesuai dengan target analisis pada masing-masing domain.

\section{EDM01-Ensure Governance Framework Setting and Maintenance}

TABEL VI

Hasil PENGUKURAn TingKat KaPABiLITAS EDM01

\begin{tabular}{|c|c|c|c|c|}
\hline $\begin{array}{c}\text { Process } \\
\text { Name }\end{array}$ & EDM01 & $\begin{array}{c}\text { Rating } \\
\text { Scale }\end{array}$ & Target & GAP \\
\hline Level 0 & & $85.00 \%$ & $100 \%$ & $15 \%$ \\
\hline Level 1 & PA 1.1 & $83.00 \%$ & $100 \%$ & $17 \%$ \\
\hline Level 2 & PA 2.1 & $78.33 \%$ & $86 \%$ & $8 \%$ \\
\hline Level 2 & PA 2.2 & $86.25 \%$ & $86 \%$ & $0 \%$ \\
\hline Level 3 & PA 3.1 & $60.00 \%$ & $86 \%$ & $26 \%$ \\
\hline Level 3 & PA 3.2 & $86.67 \%$ & $100 \%$ & $13 \%$ \\
\hline Level 4 & PA 4.1 & $74.77 \%$ & $100 \%$ & $23 \%$ \\
\hline Level 4 & PA 4.2 & $32.00 \%$ & $100 \%$ & $68 \%$ \\
\hline Level 5 & PA 5.1 & $66.00 \%$ & $90 \%$ & $24 \%$ \\
\hline Level 5 & PA 5.2 & $91.67 \%$ & $90 \%$ & $-2 \%$ \\
\hline
\end{tabular}

Berdasarkan Score Capability Level Achieved: $\mathbf{7 4 . 7 7 \%}$ pada pada Tabel VI di atas dengan Rating Scale sesuai dengan evaluasi kematangan Proses EDM01 Largely Achieved (L) atau berada pada Level 3 Established process. Gambar 8 menunjukkan visualisasi evaluasi kematangan.

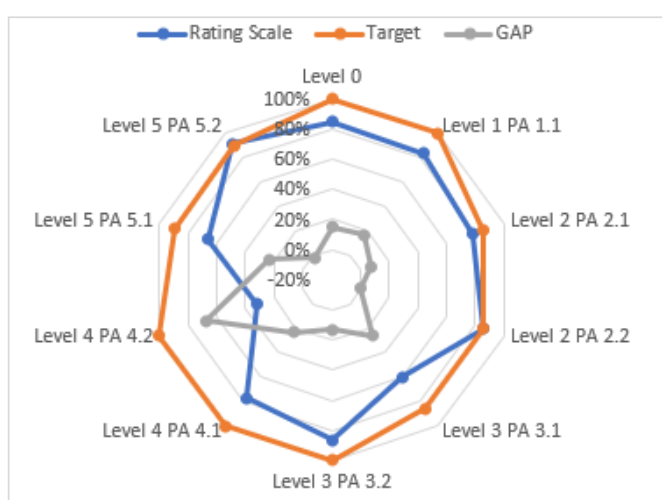

Gambar 8 EDM01-Ensure Governance Framework Setting and Maintenance

\section{E. EDM03-Ensure Risk Optimisation}

TABEL VII

Hasil PengukuRAn TingKat KaPABILITAS UNTUK EDM03

\begin{tabular}{|c|c|c|c|c|}
\hline $\begin{array}{c}\text { Process } \\
\text { Name }\end{array}$ & EDM03 & $\begin{array}{c}\text { Rating } \\
\text { Scale }\end{array}$ & Target & GAP \\
\hline Level 0 & & $85.00 \%$ & $100 \%$ & $15 \%$ \\
\hline Level 1 & PA 1.1 & $67.00 \%$ & $100 \%$ & $33 \%$ \\
\hline Level 2 & PA 2.1 & $76.66 \%$ & $86 \%$ & $9 \%$ \\
\hline Level 2 & PA 2.2 & $68.75 \%$ & $86 \%$ & $17 \%$ \\
\hline Level 3 & PA 3.1 & $64.00 \%$ & $86 \%$ & $22 \%$ \\
\hline Level 3 & PA 3.2 & $84.50 \%$ & $100 \%$ & $16 \%$ \\
\hline Level 4 & PA 4.1 & $72.00 \%$ & $100 \%$ & $28 \%$ \\
\hline Level 4 & PA 4.2 & $32.00 \%$ & $100 \%$ & $60 \%$ \\
\hline Level 5 & PA 5.1 & $12.00 \%$ & $90 \%$ & $78 \%$ \\
\hline Level 5 & PA 5.2 & $30.00 \%$ & $90 \%$ & $60 \%$ \\
\hline
\end{tabular}

Berdasarkan Score Capability Level Achieved: $\mathbf{7 2 . 0 0 \%}$ pada Tabel VII di atas dengan Rating Scale sesuai dengan evaluasi kematangan Proses EDM03 adalah Largely Achieved (L) atau berada pada Level 3 Established process. Visualisasi gambar terdapat pada Gambar 9.

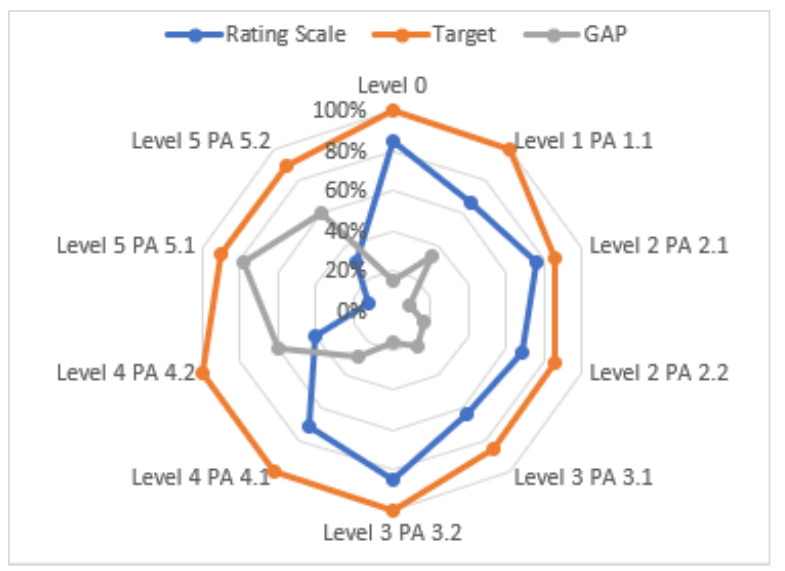

Gambar 9 Grafik Nilai Kesenjangan Proses EDM03 


\section{F. APO02-Manage Strategy}

TABEL VIII

HASIL PENGUKURAN TINGKaT KAPABILITAS UNTUK APO02

\begin{tabular}{|c|c|c|c|c|}
\hline $\begin{array}{c}\text { Process } \\
\text { Name }\end{array}$ & APO02 & $\begin{array}{c}\text { Rating } \\
\text { Scale }\end{array}$ & Target & GAP \\
\hline Level 0 & & $85.00 \%$ & $100 \%$ & $15 \%$ \\
\hline Level 1 & PA 1.1 & $98.00 \%$ & $100 \%$ & $2 \%$ \\
\hline Level 2 & PA 2.1 & $92.33 \%$ & $86 \%$ & $-6 \%$ \\
\hline Level 2 & PA 2.2 & $100 \%$ & $86 \%$ & $\begin{array}{c}- \\
14 \%\end{array}$ \\
\hline Level 3 & PA 3.1 & $80.00 \%$ & $86 \%$ & $6 \%$ \\
\hline Level 3 & PA 3.2 & $86.00 \%$ & $100 \%$ & $14 \%$ \\
\hline Level 4 & PA 4.1 & $83.00 \%$ & $100 \%$ & $17 \%$ \\
\hline Level 4 & PA 4.2 & $100 \%$ & $100 \%$ & $0 \%$ \\
\hline Level 5 & PA 5.1 & $86.00 \%$ & $90 \%$ & $4 \%$ \\
\hline Level 5 & PA 5.2 & $89.33 \%$ & $90 \%$ & $1 \%$ \\
\hline
\end{tabular}

Berdasarkan Score Capability Level Achieved: 89.33\% pada Tabel VIII di atas dengan Rating Scale sesuai dengan evaluasi kematangan Proses APO02 adalah F atau Fully Achieved atau berada pada Level 5 Optimizing. Visualisasi gambar terdapat pada Gambar 10.

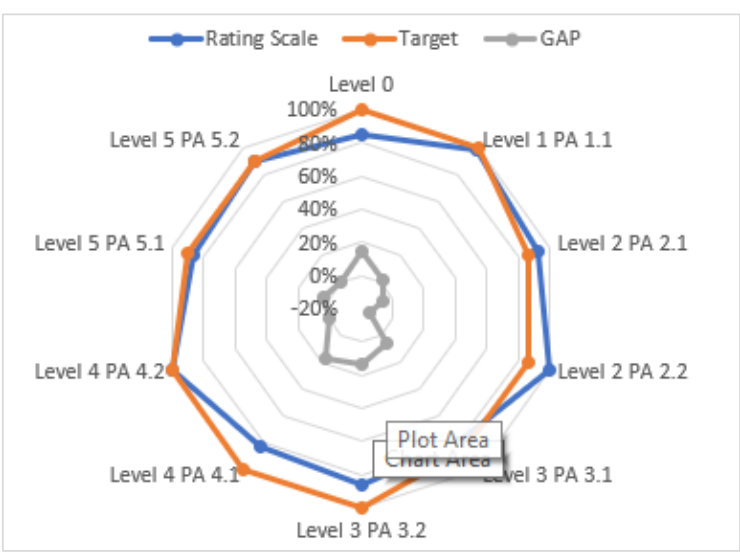

Gambar 10 Grafik Nilai Kesenjangan Proses APO02

G. APO09-Manage Service Agreements

TABEL IX

HASIL PENGUKURAN TINGKAT KAPABILITAS APO09

\begin{tabular}{|c|c|c|c|c|}
\hline $\begin{array}{c}\text { Process } \\
\text { Name }\end{array}$ & APO09 & $\begin{array}{c}\text { Rating } \\
\text { Scale }\end{array}$ & Target & GAP \\
\hline Level 0 & & $100 \%$ & $100 \%$ & $0 \%$ \\
\hline Level 1 & PA 1.1 & $78.00 \%$ & $100 \%$ & $22 \%$ \\
\hline Level 2 & PA 2.1 & $57.50 \%$ & $86 \%$ & $29 \%$ \\
\hline Level 2 & PA 2.2 & $86.25 \%$ & $86 \%$ & $0 \%$ \\
\hline Level 3 & PA 3.1 & $67.00 \%$ & $86 \%$ & $19 \%$ \\
\hline Level 3 & PA 3.2 & $60.00 \%$ & $100 \%$ & $40 \%$ \\
\hline Level 4 & PA 4.1 & $36.00 \%$ & $100 \%$ & $64 \%$ \\
\hline Level 4 & PA 4.2 & $0.00 \%$ & $100 \%$ & $100 \%$ \\
\hline Level 5 & PA 5.1 & $0.00 \%$ & $90 \%$ & $90 \%$ \\
\hline Level 5 & PA 5.2 & $0.00 \%$ & $90 \%$ & $90 \%$ \\
\hline
\end{tabular}

Berdasarkan Score Capability Level Achieved: $\mathbf{6 0 . 0 0 \%}$ pada Tabel IX dengan Rating Scale sesuai dengan evaluasi kematangan Proses APO09 adalah P atau Partialy Achieved atau berada pada Level 2 Manage Proses. Visualisasi gambar terdapat pada Gambar 11.

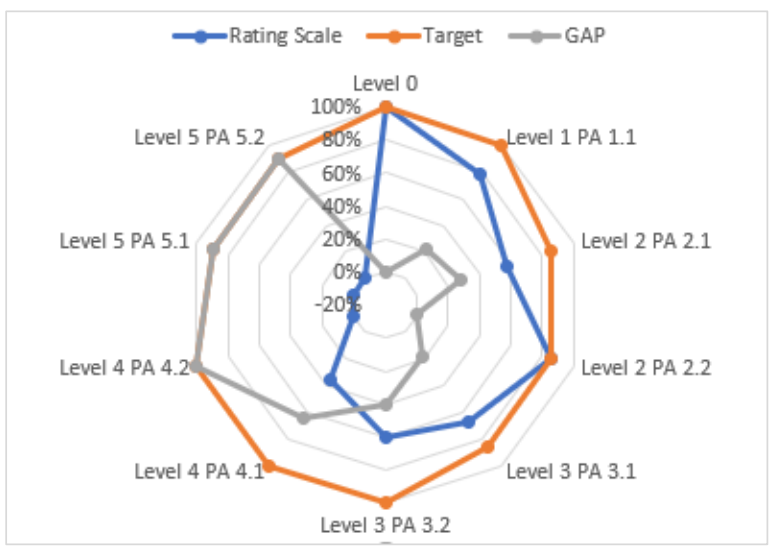

Gambar 11 Grafik Nilai Kesenjangan Proses APO09

H. BAI01-Manage Programmes and Projects

TABEL $X$

HASIL PENGUKURAN TINGKAT KAPABILITAS BAI01

\begin{tabular}{|c|c|c|c|c|}
\hline $\begin{array}{c}\text { Process } \\
\text { Name }\end{array}$ & BAI01 & $\begin{array}{c}\text { Rating } \\
\text { Scale }\end{array}$ & Target & GAP \\
\hline Level 0 & & $100 \%$ & $100 \%$ & $0 \%$ \\
\hline Level 1 & PA 1.1 & $80 \%$ & $100 \%$ & $20 \%$ \\
\hline Level 2 & PA 2.1 & $70.00 \%$ & $86 \%$ & $16 \%$ \\
\hline Level 2 & PA 2.2 & $55.00 \%$ & $86 \%$ & $31 \%$ \\
\hline Level 3 & PA 3.1 & $50 \%$ & $86 \%$ & $36 \%$ \\
\hline Level 3 & PA 3.2 & $66.36 \%$ & $100 \%$ & $40 \%$ \\
\hline Level 4 & PA 4.1 & $0 \%$ & $100 \%$ & $100 \%$ \\
\hline Level 4 & PA 4.2 & $0 \%$ & $100 \%$ & $100 \%$ \\
\hline Level 5 & PA 5.1 & $0 \%$ & $90 \%$ & $90 \%$ \\
\hline Level 5 & PA 5.2 & $0.00 \%$ & $90 \%$ & $90 \%$ \\
\hline
\end{tabular}

Berdasarkan Score Capability Level Achieved: 66.36\% pada Tabel X di atas dengan Rating Scale sesuai dengan evaluasi kematangan Proses BAI01 adalah L atau Largely Achieved atau berada pada Level 3 Established process. Visualisasi gambar terdapat pada Gambar 12. 


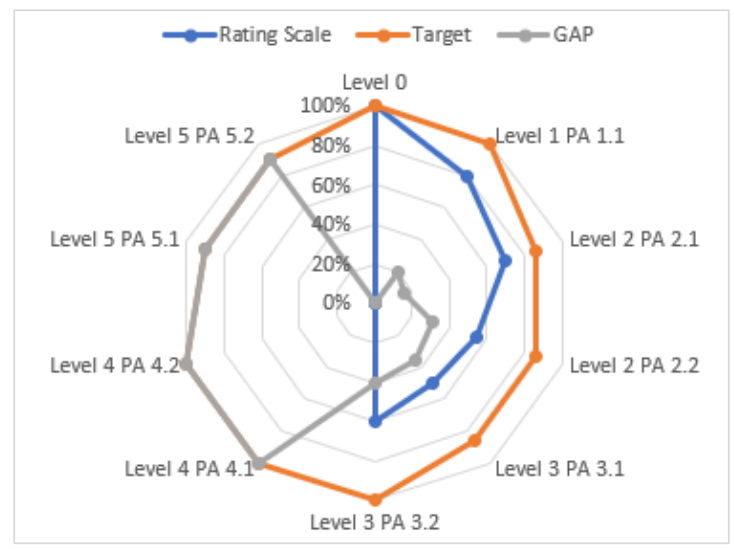

Gambar 12 Grafik Nilai Kesenjangan Proses BAI01

I. BAI05-Manage Organisational Change Enablement

TABEL XI

Hasil PenguKuran TingKat KaPABILITAS BAI05

\begin{tabular}{|c|c|c|c|c|}
\hline $\begin{array}{c}\text { Process } \\
\text { Name }\end{array}$ & BAI05 & $\begin{array}{c}\text { Rating } \\
\text { Scale }\end{array}$ & Target & GAP \\
\hline Level 0 & & $100 \%$ & $100 \%$ & $0 \%$ \\
\hline Level 1 & PA 1.1 & $82 \%$ & $100 \%$ & $18 \%$ \\
\hline Level 2 & PA 2.1 & $82.00 \%$ & $86 \%$ & $4 \%$ \\
\hline Level 2 & PA 2.2 & $82.00 \%$ & $86 \%$ & $4 \%$ \\
\hline Level 3 & PA 3.1 & $50 \%$ & $86 \%$ & $36 \%$ \\
\hline Level 3 & PA 3.2 & $50.00 \%$ & $100 \%$ & $50 \%$ \\
\hline Level 4 & PA 4.1 & $50 \%$ & $100 \%$ & $50 \%$ \\
\hline Level 4 & PA 4.2 & $0 \%$ & $100 \%$ & $100 \%$ \\
\hline Level 5 & PA 5.1 & $0 \%$ & $90 \%$ & $90 \%$ \\
\hline Level 5 & PA 5.2 & $30.00 \%$ & $90 \%$ & $60 \%$ \\
\hline
\end{tabular}

Berdasarkan Score Capability Level Achieved: 61.75\% dengan Rating Scale sesuai dengan evaluasi kematangan Proses BAI05 adalah L atau Largely Achieved atau berada pada Level 3 Established process. Visualisasi gambar terdapat pada Gambar 13.

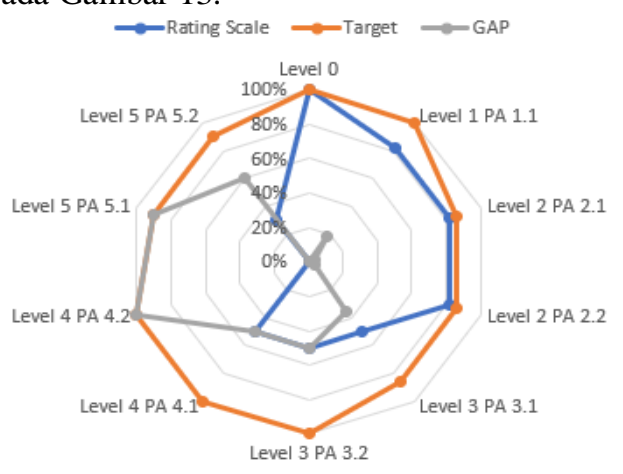

Gambar 13 Grafik Nilai Kesenjangan Proses BAI05

Proses APO12 berdasarkan Score Capability Level Achieved: 36.40\% dengan Rating Scale sesuai dengan evaluasi kematangan adalah $\mathrm{P}$ atau Partial Achieved atau berada pada Level 1 Performed process atau berhenti pada PA1.1. Proses selanjutnya tidak dilanjutkan.
Secara keseluruhan sesuai dengan hasil analisis yang sudah dilakukan untuk domain: EDM01- Ensure Governance Framework Setting and Maintenance dan EDM03- Ensure Risk Optimation, AP002- Manage Strategy, APO09- Manage Service Agreements dan AP012- Manage Risk. BAI01Manage Programmes and Projects dan BAI05- Manage Organizational Change Eneblement dapat divisualisasikan seperti pada Gambar 14.

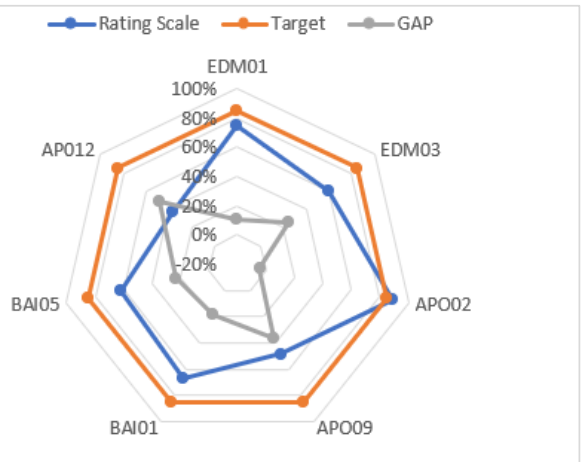

Gambar 14 Grafik Analisis Akhir 7 (tujuh) Domain

\section{J. Identifikasi Risiko}

Proses awal pada risk assesment adalah mengidentifikasi risiko sebagai antisipasi pencegahan awal ancaman yang akan dihadapi kedepan, dengan segala teori ketidakpastian, untuk keberlangsungan tata kelola TI dan tujuan organisasi. Proses identifikasi akan diturunkan berdasarkan asset IT [10] data dan application portfolio, kemudian berdasarkan risiko yang berpotensi muncul pada saat menjalankan operasional layanan Teknologi Informasi, risiko dikelompokkan berdasarkan asset TI pada Tabel XII.

TABEL XII

IDENTISIFIKASI BERDAS ARKAN ASSET

\begin{tabular}{|c|c|}
\hline Aset & Risk Issue \\
\hline Aplikasi & 2 \\
\hline Infrastruktur TI & 10 \\
\hline Proses & 5 \\
\hline Grand Total & $\mathbf{1 7}$ \\
\hline
\end{tabular}

Selanjutnya adalah identifikasi risiko berdasarkan risk scenario. Terdapat 18 daftar risk scenario yang bisa teridentifikasi seperti yang terlihat pada Tabel XIII.

TABEL XIII

IDENTIFIKASI RISK ISSUE BERDASARKAN SKENARIO

\begin{tabular}{|c|l|c|}
\hline No & \multicolumn{1}{|c|}{ Skenario } & $\begin{array}{c}\text { Jumlah } \\
\text { Risk }\end{array}$ \\
\hline 1 & $\begin{array}{l}\text { Ada perangkat wifi yang rusak, provider } \\
\text { internet putus }\end{array}$ & 1 \\
\hline 2 & $\begin{array}{l}\text { Gempa Bumi, Banjir, kebakaran dan bencana } \\
\text { alam lainnya }\end{array}$ & 1 \\
\hline 3 & Hacking ke router ISP & 1 \\
\hline 4 & Instalasi program diluar standarisasi & 1 \\
\hline
\end{tabular}




\begin{tabular}{|c|c|c|}
\hline No & Skenario & $\begin{array}{c}\text { Jumlah } \\
\text { Risk }\end{array}$ \\
\hline 5 & Ketersediaan ruangan yang terbatas & 1 \\
\hline 6 & $\begin{array}{l}\text { Kurangnya pengawasan terhadap } \\
\text { infrastruktur yang ada di unit }\end{array}$ & 1 \\
\hline 7 & $\begin{array}{l}\text { Kurangnya sosialisasi tentang prosedur } \\
\text { perbaikan barang/pengajuan komplain } \\
\text { terhadap unit-unit kerja yang ada }\end{array}$ & 1 \\
\hline 8 & $\begin{array}{l}\text { Listrik mati tiba-tiba tanpa ada } \\
\text { pemberitahuan }\end{array}$ & 1 \\
\hline 9 & $\begin{array}{l}\text { Mesin Server tiba-tiba mati tanpa ada } \\
\text { pemberitahuan }\end{array}$ & 1 \\
\hline 10 & $\begin{array}{l}\text { Pengguna layanan menggunakan aplikasi } \\
\text { yang terinfeksi virus }\end{array}$ & 1 \\
\hline 11 & $\begin{array}{l}\text { Pengguna melakukan setting perangkat yang } \\
\text { tidak sesuai dengan standar TI }\end{array}$ & 1 \\
\hline 12 & $\begin{array}{l}\text { Pengguna mengakses layanan wifi dengan } \\
\text { menggunakan akun yang bukan miliknya }\end{array}$ & 1 \\
\hline 13 & Perangkat yang rusak & 1 \\
\hline 14 & Performa aplikasi yang buruk & 1 \\
\hline 15 & $\begin{array}{l}\text { Terdapat perangkat dan atau sistem yang } \\
\text { rusak }\end{array}$ & 1 \\
\hline 16 & Tidak meng-update antivirus & 1 \\
\hline 17 & $\begin{array}{l}\text { Update aplikasi (Sistem Operasi) secara } \\
\text { otomatis di komputer pengguna layanan }\end{array}$ & 1 \\
\hline 18 & $\begin{array}{l}\text { Usia komputer yang sudah lama, kelalaian } \\
\text { pengguna layanan di dalam menggunakan } \\
\text { komputer dan fasilitas yang ada }\end{array}$ & 1 \\
\hline \multicolumn{2}{|c|}{ Grand Total } & 18 \\
\hline
\end{tabular}

Selanjutnya akan dilakukan analisis potensi risiko untuk melihat dampak dan potensi penyebab risiko, kemudian antisipasi peluang terjadinya kendali dan tindakan pencegahan (saat ini) dengan harapan ada perbaikan dan tindak lanjut yang dapat mengurangi nilai risiko. Selanjutnya melakukan proses penilaian risiko Inherrent risk dan dilanjutkan dengan Residual risk pada Tabel XIV.

TABEL XIV

HASIL PENILAIAN INHERRENT RISK

\begin{tabular}{|c|c|c|c|c|c|c|}
\hline Asset & 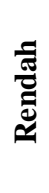 & 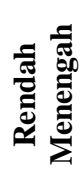 & $\begin{array}{l}\text { 륨 } \\
\text { 일 } \\
\text { 률 }\end{array}$ & 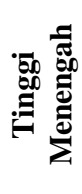 & 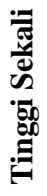 & 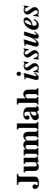 \\
\hline Aplikasi & & & 2 & & & 2 \\
\hline Infrastruktur IT & 1 & 1 & 5 & 2 & 1 & 10 \\
\hline Proses & 1 & 1 & 3 & & 1 & 6 \\
\hline Grand Total & 2 & 2 & 10 & 2 & 2 & 18 \\
\hline
\end{tabular}

Hasil yang didapatkan pada saat menghitung dan mengidentifikasi jumlah risiko yang kemungkinan terjadi tinggi sekali adalah 2, tinggi menengah adalah 2, menengah adalah 10 , rendah menengah adalah 2 dan rendah adalah 2 . Selanjutnya untuk Residual risk bisa dilihat pada Tabel XV.
TABEL XV

HASIL PENILAIAN RESIDUAL RISK

\begin{tabular}{|c|c|c|c|c|c|c|}
\hline Asset & 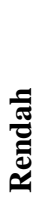 & 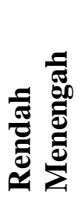 & 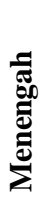 & 包 & 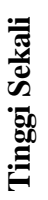 & 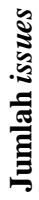 \\
\hline Aplikasi & & 2 & & & & 2 \\
\hline $\begin{array}{l}\text { Infrastruktur } \\
\mathrm{TI}\end{array}$ & 1 & 6 & 2 & & 1 & 10 \\
\hline Proses & & 4 & 1 & & 1 & 6 \\
\hline $\begin{array}{l}\text { Grand } \\
\text { Total }\end{array}$ & 1 & 12 & 3 & $\mathbf{0}$ & 2 & 18 \\
\hline
\end{tabular}

Hasil yang didapatkan pada saat menghitung dan mengidentifikasi jumlah risiko yang kemungkinan terjadi tinggi sekali adalah 2 , tinggi menengah adalah 0 , menengah adalah 3, rendah menengah adalah 12 dan rendah adalah 1 . Dengan total adalah 18, untuk total threat masih sama tetapi nilai risiko mundur beberapa nilai.

Selanjutnya untuk risk evaluation, untuk mengevaluasi perusahaan sesuai dengan toleransi bisa diberikan atau tidak. Untuk menggambarkan hubungan Impact dengan Probability akan disiapkan matriks yang dinamakan Risk Map. Pada matrik di bawah ini terlihat proses yang sesuai dengan impact dan probability.

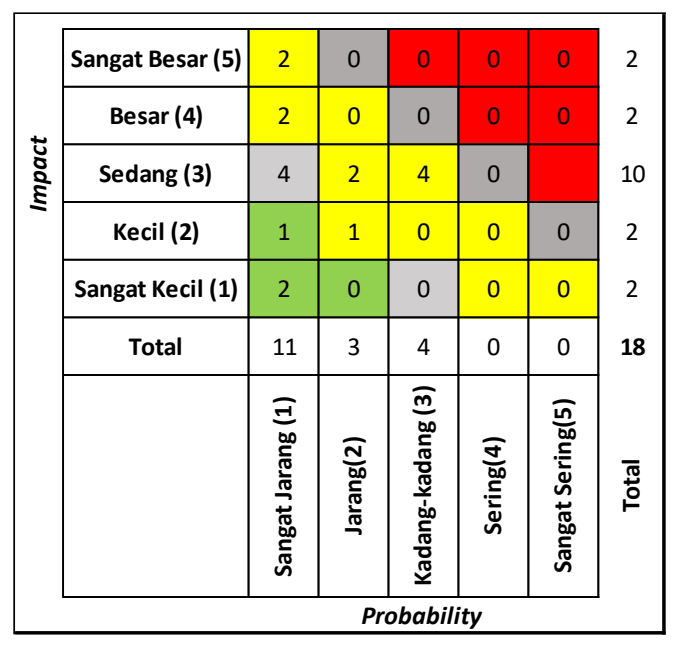

Gambar 15 Risk Map

Gambar 15 menunjukkan risk issue menengah terkait apa yang dapat dilakukan untuk tindakan pencegahan. Penjelasan 4 (empat) risk issue yang dimaksud terlampir pada Tabel XVI. 
TABEL XVI

DAFTAR RISK ISSUES

\begin{tabular}{|c|c|c|c|c|c|}
\hline 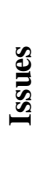 & 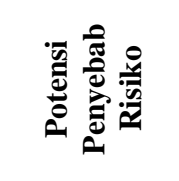 & م. & 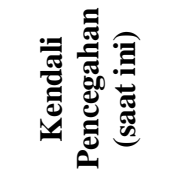 & 章 & 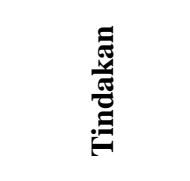 \\
\hline 1 & $\begin{array}{l}\text { Pengguna } \\
\text { layanan } \\
\text { menggunaka } \\
\mathrm{n} \text { aplikasi } \\
\text { yang } \\
\text { terinfeksi } \\
\text { virus }\end{array}$ & 3 & & 9 & $\begin{array}{l}\text { Sosialisasi } \\
\text { terkait } \\
\text { kemungkinan } \\
\text { penyebab } \\
\text { penyebaran } \\
\text { virus }\end{array}$ \\
\hline 2 & $\begin{array}{l}\text { Terdapat } \\
\text { perangkat } \\
\text { dan atau } \\
\text { sistem yang } \\
\text { rusak }\end{array}$ & 3 & $\begin{array}{l}\text { Memastikan } \\
\text { kondisi dan } \\
\text { kinerja } \\
\text { setiap server } \\
\text { berjalan } \\
\text { dengan } \\
\text { semestinya }\end{array}$ & 9 & $\begin{array}{l}\text { Memonitoring } \\
\text { dan } \\
\text { mengevaluasi } \\
\text { perangkat dan } \\
\text { sistem server } \\
\text { secara berkala }\end{array}$ \\
\hline 3 & $\begin{array}{l}\text { Update } \\
\text { aplikasi } \\
\text { (Sistem } \\
\text { Operasi) } \\
\text { secara } \\
\text { otomatis di } \\
\text { komputer } \\
\text { pengguna } \\
\text { layanan }\end{array}$ & 3 & $\begin{array}{l}\text { Monitoring } \\
\text { penggunaan } \\
\text { wifi per } \\
\text { pengguna } \\
\text { layanan }\end{array}$ & 9 & $\begin{array}{l}\text { Memberikan } \\
\text { penjelasan } \\
\text { kepada } \\
\text { pengguna } \\
\text { terkait } \\
\text { kemungkinan } \\
\text { penyebab } \\
\text { kuota wifi } \\
\text { habis }\end{array}$ \\
\hline 4 & $\begin{array}{l}\text { Perangkat } \\
\text { yang rusak }\end{array}$ & 3 & $\begin{array}{l}\text { Mengganti } \\
\text { perangkat } \\
\text { yang rusak } \\
\text { dengan } \\
\text { perangkat } \\
\text { baru }\end{array}$ & 9 & $\begin{array}{l}\text { Menyediakan } \\
\text { perangkat } \\
\text { cadangan }\end{array}$ \\
\hline
\end{tabular}

\section{K. Hasil Temuan dan Rekomendasi Domain COBIT 5}

Sesuai dengan risk assesment dan anasilis kapabilitas yang sudah dilakukan menunjukkan bahwa kerangka COBIT 5 juga dapat digunakan untuk memastikan bahwa tujuan TI selaras dengan tujuan bisnis organisasi, memungkinkan untuk memaksimalkan keuntungan, sumber daya telah digunakan secara bertanggung jawab dan risiko TI dikelola dengan tepat. Secara spesifik temuan dan rekomendasi terdapat pada Tabel XVII.

\section{TABEL XVII}

HASIL TEMUAN DAN REKOMENDASI

\begin{tabular}{|l|l|}
\hline Kode & \multicolumn{1}{|c|}{ Hasil Temuan dan Rekomendasi } \\
\hline \multirow{6}{*}{ R1 } & $\begin{array}{l}\text { Berdasarkan temuan EDM01-Ensure Governance } \\
\text { Framework Setting and Maintenance berdasarkan Score } \\
\text { Capability Level Achieved: 74.77\% dengan rating scale } \\
\text { sesuai dengan evaluasi kematangan Proses EDM01 } \\
\text { adalah L atau Largely Achieved atau berada pada Level } \\
\text { 3 Established process. Pada titik ini sudah optimal dan } \\
\text { sudah mendekati score ideal. Direkomendasikan kepada } \\
\text { pemangku kepentingan agar memastikan adanya } \\
\text { evaluasi dalam sistem Tata Kelola. Memastikan adanya }\end{array}$ \\
\hline
\end{tabular}

\begin{tabular}{|c|c|}
\hline Kode & Hasil Temuan dan Rekomendasi \\
\hline & $\begin{array}{l}\text { pengarahan sistem Tata Kelola dan memastikan adanya } \\
\text { monitoring sistem Tata Kelola. }\end{array}$ \\
\hline $\mathrm{R} 2$ & $\begin{array}{l}\text { Berdasarkan temuan pada area control domain APO02- } \\
\text { Manage Strategy terkait dengan implementasi tujuan } \\
\text { strategi universitas pada level ini. Level ini penting } \\
\text { untuk selalu mendapatkan feedback dari stakeholders } \\
\text { internal dan komunikasi setiap pemangku kepentingan } \\
\text { dan pelaku level operasional agar tujuan organisasi } \\
\text { memiliki pemahaman tentang tujuan perusahaan dan } \\
\text { program kerja yang selaras. Direkomendasikan agar } \\
\text { memastikan tata kelola universitas yang transparan dan } \\
\text { adanya keselarasan model bisnis, tujuan organisasi, } \\
\text { berkesinambungan dan berkelanjutan. }\end{array}$ \\
\hline R3 & $\begin{array}{l}\text { Berdasarkan temuan pada area control domain EDM03- } \\
\text { Ensure Risk Optimisation. Score Capability Level } \\
\text { Achieved: 59.93\% dengan rating scale sesuai dengan } \\
\text { evaluasi kematangan proses EDM03 adalah L atau } \\
\text { Level } 3 \text { Established process. Sering terjadi gangguan } \\
\text { layanan TI yang berulang atau komplain kasus IT yang } \\
\text { sama. Direkomendasikan pengelolaan risk dan service } \\
\text { agar melakukan penguatan pada DSS03: Manage } \\
\text { Problems / Mengelola Masalah TI. }\end{array}$ \\
\hline R4 & $\begin{array}{l}\text { Berdasarkan temuan pada area control domain APO09- } \\
\text { Manage Service Agreements Request terdapat layanan } \\
\text { yang tidak memiliki policy atau SOP Layanan yang } \\
\text { mengakomodasikan adaptasi terhadap perubahan. } \\
\text { Direkomendasikan untuk dilakukan penguatan pada } \\
\text { DSS03: Manage Problems khususnya mengelola } \\
\text { masalah TI. }\end{array}$ \\
\hline R5 & $\begin{array}{l}\text { Berdasarkan temuan pada area control domain APO12- } \\
\text { Manage Risk Score. Capability Level Achieved: 36.4\% } \\
\text { dengan rating scale sesuai dengan evaluasi kematangan } \\
\text { Proses APO12 adalah Level } 1 \text { Performed process. } \\
\text { Dalam rangka menuju level yang lebih ideal, Divisi } \\
\text { Sistem Informasi Perguruan Tinggi XYZ harus lebih } \\
\text { banyak menyiapkan dokumen bukti terkait manajemen } \\
\text { risiko pencapaian sistematis dari tujuan proses. } \\
\text { Direkomendasikan saat ini perlu mengintegrasikan } \\
\text { semua risiko dalam organisasi menyeluruh dalam area } \\
\text { tata kelola yang lebih luas untuk maintain a risk profile, } \\
\text { articulate risk, define a risk management action } \\
\text { portfolio, monitor and review dan level saat ini level } \\
\text { perfomed perlu ditingkatkan sampai pada tingkat level } \\
\text { optimised dan mengelola risiko secara terpadu dan } \\
\text { terintegrasi. }\end{array}$ \\
\hline R6 & $\begin{array}{l}\text { Berdasarkan temuan pada area control domain BAI01- } \\
\text { Manage Programmes and Projects. Score Capability } \\
\text { Level Achieved: 66.36\% dengan rating scale sesuai } \\
\text { dengan evaluasi kematangan Proses BAI01 adalah } \\
\text { Level } 3 \text { Established process. Kurangnya ketersediaan } \\
\text { SDM. Dukungan pengembangan hanya pada area } \\
\text { application portfolio utama atau dalam solusi } \\
\text { pengembangan melibatkan pihak ketiga. } \\
\text { Direkomendasikan atau memperjelas target dan } \\
\text { meningkatkan kapabilitas TI dan mengarahkan pada } \\
\text { GAP analisis yang terukur. Untuk sumber daya (SDM) } \\
\text { disarankan untuk penguatan pada APO07.02 Identify } \\
\text { key IT personnel dan APO07.03 Maintain the skills and } \\
\text { competencies of personnel. APO07.04 Evaluate } \\
\text { employee job performance. Pengembangan diharapkan } \\
\text { tidak hanya spesifik pada application portfolio utama, }\end{array}$ \\
\hline
\end{tabular}




\begin{tabular}{|c|c|}
\hline Kode & Hasil Temuan dan Rekomendasi \\
\hline & $\begin{array}{l}\text { tetapi secara menyeluruh sesuai dengan kebijakan } \\
\text { strategi dan tujuan organisasi. Keterlibatan pihak ketiga } \\
\text { merupakan hal yang tidak dapat dihindarkan, tetapi hal } \\
\text { ini dapat diatasi dengan penguatan Security Policy Third } \\
\text { Party dan penambahan SOP yang mengatur otorisasi } \\
\text { dan persetujuan bertingkat untuk pemanfaatan data } \\
\text { asset TI yang tepat guna dan sesuai tujuan yang } \\
\text { seharusnya. }\end{array}$ \\
\hline R7 & $\begin{array}{l}\text { Berdasarkan temuan pada area control domain BAI05- } \\
\text { Manage Organisational Change Enablement. Score } \\
\text { Capability Level Achieved: 61.75\% dengan rating scale } \\
\text { sesuai dengan evaluasi kematangan Proses BAI05 } \\
\text { adalah Level } 3 \text { Established process. Direkomendasikan } \\
\text { dalam beradaptasi dan mengakomodasi titik perubahan, } \\
\text { tata kelola organisasi harus memperkuat BAI05.1, } \\
\text { pendekatan yang baru (BAI05.06) yang melekat pada } \\
\text { organisasi dan mempertahankan perubahan pada arah } \\
\text { yang konsisten positif (BAI05.07). }\end{array}$ \\
\hline
\end{tabular}

Rekomendasikan yang disajikan untuk perbaikan yang diusulkan seperti Tabel XVII di atas dengan mengajukan usulan yang bisa digunakan pimpinan dalam mengambil keputusan, proses mana yang bersifat urgent [11] yang dapat ditindaklanjuti untuk perbaikan performance pada masa yang akan datang, tersaji pada Tabel XVIII.

TABEL XVIII

PRIORITAS REKOMENDASI

\begin{tabular}{|c|c|c|}
\hline & Urgent & Not Urgent \\
\hline Important & $\begin{array}{l}\text { Do } \\
\text { R6 } \\
\text { R5 }\end{array}$ & $\begin{array}{c}\text { Decide } \\
\text { R1, R2, R3 } \\
\text { R4 }\end{array}$ \\
\hline $\begin{array}{c}\text { Not } \\
\text { important }\end{array}$ & $\begin{array}{c}\text { Delegate } \\
\text { R7 }\end{array}$ & $\begin{array}{c}\text { Delete (if } \\
\text { possible) } \\
-\end{array}$ \\
\hline
\end{tabular}

Hasil matriks pada Tabel XVIII adalah pemetaan Tabel XVII menunjukkan bahwa hal yang dapat dijadikan prioritas untuk dapat segera ditindaklanjuti oleh pimpinan adalah R5 atau untuk mengintegrasikan semua risiko dalam organisasi menyeluruh dalam area tata kelola yang lebih luas untuk maintain a risk profile, articulate risk, define a risk management action portfolio, monitor and review dan level saat ini level perfomed perlu ditingkatkan sampai pada tingkat level optimised dan mengelola risiko secara terpadu dan terintegrasi.

Rekomendasi selanjutnya adalah R6 atau memperjelas target dan meningkatkan kapabilitas TI dan mengarahkan pada gap analisis yang terukur. Untuk sumber daya (SDM) disarankan untuk penguatan pada APO07.02 Identify key IT personnel dan APO07.03 Maintain the skills and competencies of personnel. APO07.04 Evaluate employee job performance. Pengembangan diharapkan tidak hanya spesifik pada application portfolio utama, tetapi secara menyeluruh yang sesuai dengan kebijakan strategi dan tujuan organisasi. Keterlibatan pihak ketiga merupakan hal yang tidak dapat dihindarkan, tetapi hal ini dapat diatasi dengan penguatan Security Policy Third Party dan penambahan SOP yang mengatur otorisasi dan persetujuan bertingkat untuk pemanfaatan data asset TI yang tepat guna dan sesuai tujuan yang seharusnya.

\section{SIMPULAN}

Sesuai dengan tujuan penelitian dan rumusan masalah yang sudah ditentukan maka kesimpulan yang dapat diambil saat ini adalah:

1. Berdasarkan hasil analisis kapabilitas AP012 Manage Risk, proses ini berada pada Level 1 Performed process atau sebesar $36.4 \%$ dengan ini hipotesis $\mathrm{H}_{1}$ dan $\mathrm{H}_{2}$ dinyatakan memenuhi.

2. Kerangka COBIT 5 sangat membantu untuk memastikan bahwa tujuan TI selaras dengan tujuan bisnis organisasi memungkinkan untuk memaksimalkan keuntungan, sumber daya digunakan secara bertanggung jawab dan risiko TI dikelola dengan tepat.

Dengan adanya beberapa keterbatasan yang dilakukan dalam penelitian ini, berikut beberapa saran yang dapat diberikan untuk peningkatan penelitian yang akan dilakukan selanjutnya, yaitu agar memperhatikan hal-hal berikut:

1. Penelitian yang dilakukan pada masa yang akan datang dapat menambah jumlah domain area control yang akan dianalisis dengan menggunakan framework COBIT 2019 dengan adjustment pada framework audit yang terbaru.

2. Penelitian yang akan datang agar memperkuat proses penyusunan Rencana Audit baik untuk penyusunan daftar pertanyaan sampai pada pengumpulan bukti untuk menghindari kelemahan atau kemungkinan yang bisa terjadi yaitu subjektifitas pertanyaan.

3. Harapannya dalam mengelola risiko atau mengelola program dan proyek Divisi Sistem Informasi Perguruan Tinggi XYZ perlu untuk meningkatkan pada Level 3 Established atau di atasnya. Cara untuk meningkatkan sesuai dengan semua rekomendasi yang sudah dituliskan pada Tabel XVII yang sesuai dengan urutan urgensitas prioritas rekomendasi.

\section{UCAPAN TERIMA KASIH}

Mengucap syukur kehadirat Tuhan Yang Maha Kuasa, atas berkat rahmat-Nya jurnal akhisnya jurnal ini bisa selesai sampai pada akhir. Terima kasih kepada semua pihak yang sudah membantu. Narasumber dan semua pihak yang sudah membantu pada saat pengumpulan data, wawancara. Penyusunan ini dapat selesai dengan tidak ada kendala yang berarti. Atas bantuan yang sudah diberikan baik dukungan moril dan materil saya sampaikan terima kasih.

\section{DAFTAR PUSTAKA}

[1] R. D. Lisa, "Service Level Agreement Template (SLA)," 2014.

[2] Rektor Universitas XYZ, Surat Keputusan Rektor Universitas XYZ Nomor: 131/SK/ORG/XYZ/VI/2018 tentang Struktur Ketatapamongan Universitas XYZ. 2018. 
[3] L.J. SUSILO, V.R. RIWU KAHO. "Manajemen Risiko Berbasis ISO 31000:2018, Panduan untuk Risk Leader dan Risk Practitioners". Grasindo, Jakarta, 2018.

[4] (2020) "Tata Kelola TI". [Online]. Available: https://netsolution.co.id/apa-yang-dimaksud-tata-kelola-ti-itgovernance.

[5] Information Systems Audit and Control Association, Ed., COBIT® 5: a business framework for the governance and management of enterprise IT: an ISACA® framework. Rolling Meadows, IL: ISACA, 2012.

[6] ISACA. COBIT® 5 Process Assessment Model (PAM): Using COBIT 5. IL, USA: ISACA. 2012.
[7] Yayasan Perguruan Tinggi XYZ, Surat Keputusan Yayasan Perguruan Tinggi XYZ Nomor: 823/SK/YPTXYZ/II/2016 tentang Statuta Universitas XYZ. 2016.

[8] L. D. Oktaviana, P. Pribadi, and M. Sabrinawati, "Evaluasi IT Governance Menggunakan Framework COBIT 5 (Studi Kasus: PT. XYZ)," vol. 12, p. 13, 2019.

[9] ISACA. COBIT® 5 Enabling Processes. IL, USA: ISACA. 2012.

[10] R. Habibi and I. Firmansyah, "Model Penilaian Risiko Aset Teknologi Informasi Menggunakan ISO 31000 Dan ISO/IEC 27001. Studi Kasus: Politeknik Pos Indonesia (POLTEKPOS),” p. 6, 2017.

[11] (2021) "Referensi Eisenhower matrix". [Online]. Available: https://www.eisenhower.me/eisenhower-matrix/. 